\section{Brushing Reduces Thrips and Aphid Populations on Some Greenhouse- grown Vegetable Transplants}

\author{
Joyce G. Latimer ${ }^{1}$ and Ronald D. Oetting ${ }^{2}$ \\ Georgia Experiment Station, University of Georgia, Griffin, GA 30223-1797 \\ Additional index words. mechanical stress, drought conditioning, pest resistance, tomato, \\ Lycopersicon esculentum, eggplant, Solanum melongena var. esculentum, watermelon, \\ Citrullus lanatus, Frankliniella occidentalis, Myzus persicae, IPM
}

\begin{abstract}
Sunny' tomato (Lycopersicon esculentum Mill.), 'Black Beauty' eggplant (Solanum melongena var. esculentum L. Nees.), or 'Sugar Baby' watermelon [Citrullus lanatus (Thunb.) Matsum. \& Nakai] were nontreated, subjected to brushing (20 strokes twice daily) or drought conditioning ( 2 hours daily wilt), or maintained undisturbed using ebband-flow irrigation. One week after brushing or drought conditioning, plants were inoculated with western flower thrips (Frankliniella occidentalis Pergande) or green peach aphid (Myzus persicae Sulzer). Brushing and drought conditioning reduced plant height and shoot dry weight of all crops. Brushing of all three species generally reduced the number of thrips, as indicated by number of feeding scars or percent leaf area damaged. Drought conditioning did not affect thrips populations consistently. Undisturbed plants grown with ebb-and-flow irrigation exhibited the greatest damage from thrips. Brushing reduced the number of aphids on tomato relative to the nontreated controls. Drought did not reduce aphid populations consistently on any crop. Brushing for height control may be advantageous in an integrated pest-management program to control aphids and thrips.
\end{abstract}

Brushing vegetable seedlings is a nonchemical way of controlling growth during greenhouse production that improves the overall quality of transplants (Latimer, 1991). Growing interest in brushing to control the height of transplants dictates a need to determine how the treatment fits with the overall production system. In previous experiments (Latimer and Oetting, unpublished), there were differences in thrips damage on plants subjected to brushing or drought conditioning. Although, to our knowledge, there have been no reports on the direct effect of mechanicalstress conditioning on pest tolerance, mild plant wounding via defoliation or leaf abrasion is generally detrimental to insect feeding or reproduction (Smith, 1988). However, mechanical stress may elicit ethylene production in some species (Jaffe and Telewski, 1984), which may attract insects (Campbell, 1988).

Aphid population development on plants subjected to drought stress depends on the aphid and plant species and the intensity of stress (Wearing, 1967). Moderate drought increased aphid populations (White, 1984), whereas severe drought reduced aphid fecundity (Tingey and Singh, 1980) in various species. Thrips survival is reduced under low humidity (Shipp and Gillepsie, 1993), which would be expected under drought-stress con-

Received for publication 9 Feb. 1994. Accepted for publication 27 May 1994. The cost of publishing this paper was defrayed in part by the payment of page charges. Under postal regulations, this paper therefore must be hereby marked advertisement solely to indicate this fact.

${ }^{1}$ Associate Professor, Horticulture.

${ }^{2}$ Professor, Entomology. ditions. Overhead plant irrigation induced larger aphid populations than those present on undisturbed plants watered by capillary mats (Wyatt, 1969). To determine the impact of brushing or drought conditioning on plant height control for an integrated pest-management (IPM) program in the greenhouse, we examined the effect of these treatments on thrips or aphid populations on vegetable transplants compared to nontreated plants that were irrigated by either overhead or ebb-and-flow systems.

\section{Materials and Methods}

Plant culture and conditioning treatments. For all experiments described, seeds of tomato ('Sunny'), eggplant ('Black Beauty'), or watermelon ('Sugar Baby') were planted into plastic cell-packs (cell dimensions, $3.8 \times 3.8 \times$ $6.0 \mathrm{~cm} ; 18 \mathrm{~cm}^{3}$ ) filled with a peatlite medium (Redi-Earth; Grace-Sierra, Cambridge, Mass.). Seeds were sown two per cell and thinned to one plant percell $\approx 10$ days after seeding (DAS). Seeding date varied slightly among species to synchronize all plants at the cotyledonary stage. ated at the cotyledonary stage (10 to 14 DAS). Plants were brushed back and forth across the flat with a wooden pole for a total of 40 strokes twice daily. The height of the bar was adjusted as necessary to strike only the upper one-third of shoots (Baden and Latimer, 1992). Flats of each species were elevated with wooden slats as necessary to maintain a uniform canopy height. Drought-conditioned plants were subjected to $\approx 2 \mathrm{~h}$ of visible wilt daily, measured from the initial flagging of leaves. The intensity of the drought treatment increased with Brushing and drought conditioning were initi- increased plant size. Nontreated plants were not intentionally disturbed, except for overhead irrigation applied daily or more frequently, if necessary, to maintain stress-free plants. The plant species were arranged in a strip-plot design with species stripped down the bench and treatments stripped perpendicular across the bench. An ebb-and-flow treatment was added as an undisturbed control. Each treatment was replicated four times. Greenhouse air for the experiment averaged $29 / 21 \mathrm{C}$ in 1992 and 31/21C (day/night) in 1993. Photosynthetic photon flux (PPF) averaged 10.2 and $12.8 \mathrm{~mol} \cdot \mathrm{m}^{-2} \cdot$ day $^{-1}$ in 1992 and 1993 , respectively. All plants were fertilized twice weekly at $200 \mathrm{ppm} \mathrm{N}$ with $20 \mathrm{~N}-8.7 \mathrm{P}-16.6 \mathrm{~K}$ (Grace Sierra) beginning 7 DAS. Each experiment was set up in a separate $49-\mathrm{m}^{2}$ polyethylene greenhouse.

At the conclusion of each experiment, six plants per subplot were harvested for measurement of stem length and shoot dry weight (after $72 \mathrm{~h}$ at $70 \mathrm{C}$ in a forced-air oven). For determination of insect damage, each flat was divided into 24-plant quadrants. Thrips populations are difficult to determine; adults are reclusive and rarely seen on plants, but immature thrips can usually be found on the leaves (Higgins, 1992). However, feeding scars and leaf area damage are good estimates of thrips populations (Broadbent et al., 1990) and were used to estimate the thrips population on the treated plants. Individual aphids per plant were counted. Insect counts or estimates of percentage of leaf area damage were made over all the plants in each quadrant, providing four subsamples per replication.

Thrips. Western flower thrips were collected from portulaca (P. grandiflora L. Hook) by shaking the flowers over a white pan and brushing the thrips (all stages of development) from the pan into a 50-dram vial. The thrips population collected was composed of $\approx 75 \%$ adults and $25 \%$ first and second instars. Thrips were introduced to experimental plants by placing the open vials in a $28 \times 42-\mathrm{cm}$ pan containing $2 \mathrm{~cm}$ potting medium and portulaca flowers and leaves. Thrips-free portulaca flowers, on which immature thrips could complete development, were replenished daily for 7 days. These pans were placed on benches on each side of and $1.5 \mathrm{~m}$ away from the experimental plants, one pan per replication. Each pan contained $\approx 500$ thrips. Seeding for the first thrips test was in June 1992 and included eggplant (15th), watermelon (16th), and tomato (18th). Brushing and drought treatments were initiated 29 June, and thrips were introduced on 6 July. Plants were harvested to measure growth and to count thrips feeding scars 3 weeks after pest introduction. The second thrips test was conducted in May 1993 using eggplant (seeded on the 17th), watermelon (19th), and tomato (14th). Brushing and drought treatments were initiated 27 May, and thrips were introduced 3 June. Because thrips populations were larger in 1993, plants were harvested to measure growth and to count thrips feeding scars or to estimate percent leaf area damage 2 weeks after thrips introduction.

Aphid. The pest colony used in the aphid 
tests consisted of green peach aphids maintained on chrysanthemum [Dendranthema $\times$ grandiflorum (Ramat.) Kitamura] hosts. The aphids were placed on the vegetable plants by removing the aphids individually from the chrysanthemum leaf and placing each aphid on the top of the vegetable leaf using a camelhair paintbrush. Because aphid development is rapid, aphids in all development stages were added at random. Plants were overheadirrigated $6 \mathrm{~h}$ after aphid introduction. Seeding for the first of two aphid tests was in Apr. 1993 and included eggplant (16th), watermelon (19th), and tomato (20th). Conditioning treatments were initiated $30 \mathrm{Apr}$. On 12 May, one aphid was applied for every two plants, 36 aphids per flat. Four weeks after introduction, plants were harvested to measure growth (six plants per treatment), and all aphids were counted in each quadrant of the flat. The second test with aphids started in May 1993, with the seeding of only eggplant (31th) and tomato (28th). Brushing and drought conditioning were initiated 9 June, and one aphid per plant was introduced 18 June. Aphid populations were counted 4 weeks after pest introduction. Due to an incidental infestation of thrips in both tests with aphids, we also counted the number of thrips feeding scars or estimated the percentage of leaf area damaged by thrips feeding.

Statistical analysis. All data were analyzed by SAS's (Littell et al., 1991) general linear models procedure, and means were separated by Fisher's protected least significant difference at $P<0.05$. Because pest populations and damage varied significantly across the quadrants of the flat, counts for the quadrants were averaged for one mean per replication. All aphid or feeding scar counts are expressed on a per-plant basis.

\section{Results and Discussion}

Of the three crops tested, thrips and aphids damaged eggplant the most. Thrips feeding scar counts on eggplant averaged 7 per plant, which was significantly higher than the 2 per plant on tomato or watermelon $(P<0.05)$. Aphid counts on eggplant averaged 17 per plant, which was significantly higher than the 1 per plant on tomato or the 0.2 per plant on watermelon $(P<0.05)$. Due to significant interactions, the treatment data are presented by species and, for ease of comparison, are grouped by species instead of experiment.

Thrips. Brushing and drought conditioning reduced stem length and shoot dry weight of tomato plants in the June 1992 and May 1993 thrips tests relative to nontreated controls (Table 1). In 1992 and 1993, the number of thrips feeding scars was reduced $61 \%$ and $34 \%$ on brushed plants relative to the nontreated plants, respectively. A $30 \%$ to $50 \%$ reduction in thrips populations would significantly reduce further population development, which would be advantageous in IPM. Under the lighter 1992 infestation, drought-stressed plants had fewer feeding scars than the nontreated plants, but in 1993, they had as much damage as the nontreated plants. The effect of

Table 1. Effect of conditioning treatment on plant growth and thrips damage of greenhouse-grown tomato plants.

\begin{tabular}{|c|c|c|c|c|}
\hline \multirow[b]{2}{*}{ Treatment } & \multirow[b]{2}{*}{$\begin{array}{l}\text { Stem length } \\
(\mathrm{cm})\end{array}$} & \multirow[b]{2}{*}{$\begin{array}{l}\text { Shoot dry wt } \\
(\mathrm{mg})\end{array}$} & \multicolumn{2}{|c|}{ Thrips } \\
\hline & & & $\begin{array}{c}\text { Feeding } \\
\text { scars/plant }\end{array}$ & $\begin{array}{c}\text { Leaf area } \\
\text { damaged }(\%)\end{array}$ \\
\hline \multicolumn{5}{|l|}{ June 1992} \\
\hline Nontreated $^{z}$ & $21.9 \mathrm{a}^{\mathrm{y}}$ & $552 \mathrm{a}$ & $3.6 \mathrm{a}$ & --- \\
\hline Brushed & $12.9 \mathrm{c}$ & $455 \mathrm{bc}$ & $1.4 \mathrm{~b}$ & --- \\
\hline Drought & $12.8 \mathrm{c}$ & $424 \mathrm{c}$ & $2.0 \mathrm{~b}$ & --- \\
\hline Ebb and flow & $17.6 \mathrm{~b}$ & $512 a b$ & $1.1 \mathrm{~b}$ & --- \\
\hline \multicolumn{5}{|l|}{ May 1993} \\
\hline Nontreated $^{z}$ & $33.1 \mathrm{~b}$ & $1110 \mathrm{~b}$ & $10.1 \mathrm{~b}$ & $10 \mathrm{bc}$ \\
\hline Brushed & $22.1 \mathrm{c}$ & $746 \mathrm{c}$ & $6.7 \mathrm{c}$ & $7 \mathrm{c}$ \\
\hline Drought & $16.6 \mathrm{~d}$ & $499 \mathrm{~d}$ & $12.4 \mathrm{~b}$ & $18 \mathrm{ab}$ \\
\hline Ebb and flow & $47.5 \mathrm{a}$ & $1230 \mathrm{a}$ & $22.7 \mathrm{a}$ & $22 \mathrm{a}$ \\
\hline
\end{tabular}

${ }^{2}$ Nontreated, but overhead-irrigated.

'Mean separation within column and year by Fisher's protected LSD at $P<0.05$.

Table 2. Effect of conditioning treatment on plant growth and thrips damage of greenhouse-grown watermelon or eggplant.

\begin{tabular}{|c|c|c|c|c|}
\hline \multirow[b]{2}{*}{$\begin{array}{l}\text { Crop and } \\
\text { treatment }\end{array}$} & \multirow[b]{2}{*}{$\begin{array}{l}\text { Stem length } \\
(\mathrm{cm})\end{array}$} & \multirow[b]{2}{*}{$\begin{array}{l}\text { Shoot dry wt } \\
\text { (mg) }\end{array}$} & \multicolumn{2}{|c|}{ Thrips } \\
\hline & & & $\begin{array}{c}\text { Feeding } \\
\text { scars/plant }\end{array}$ & $\begin{array}{c}\text { Leaf area } \\
\text { damaged }(\%)\end{array}$ \\
\hline \multicolumn{5}{|c|}{ Watermelon_June 1992} \\
\hline Nontreated $^{\mathrm{z}}$ & $25.1 \mathrm{a}^{y}$ & $867 \mathrm{a}$ & $3.0 \mathrm{a}$ & --- \\
\hline Brushed & $17.9 \mathrm{~b}$ & $597 \mathrm{~b}$ & $1.5 \mathrm{~b}$ & --- \\
\hline Drought & $16.8 \mathrm{c}$ & $528 \mathrm{c}$ & $1.4 \mathrm{~b}$ & --- \\
\hline Ebb and flow & $17.7 \mathrm{~b}$ & $551 \mathrm{bc}$ & $0.8 \mathrm{c}$ & --- \\
\hline \multicolumn{5}{|c|}{ Eggplant_June 1992} \\
\hline Nontreated $^{\mathrm{z}}$ & $21.4 \mathrm{a}$ & $931 \mathrm{a}$ & $4.5 \mathrm{~b}$ & --- \\
\hline Brushed & $13.4 \mathrm{~b}$ & $734 \mathrm{~b}$ & $1.3 \mathrm{c}$ & --- \\
\hline Drought & $9.9 \mathrm{c}$ & $551 \mathrm{c}$ & $1.8 \mathrm{bc}$ & --- \\
\hline Ebb and flow & $14.1 \mathrm{~b}$ & $508 \mathrm{c}$ & $20.5 \mathrm{a}$ & --- \\
\hline \multicolumn{5}{|c|}{ Eggplant-May 1993} \\
\hline Nontreated $^{z}$ & $14.7 \mathrm{~b}$ & $519 \mathrm{a}$ & $---x$ & $28 \mathrm{~b}$ \\
\hline Brushed & $11.4 \mathrm{c}$ & $479 \mathrm{~b}$ & --- & $8 \mathrm{c}$ \\
\hline Drought & $7.3 \mathrm{~d}$ & $241 \mathrm{c}$ & --- & $21 \mathrm{~b}$ \\
\hline Ebb and flow & $15.5 \mathrm{a}$ & $460 \mathrm{~b}$ & --- & $72 \mathrm{a}$ \\
\hline
\end{tabular}

${ }^{2}$ Nontreated, but overhead-irrigated.

y Mean separation within column, crop, and year by Fisher's protected LSD at $P<0.05$.

${ }^{x}$ Due to extensive feeding damage, individual scars could not be detected.

ebb-and-flow irrigation on growth and thrips damage varied between the two years. In 1993, but not in 1992, the plants produced under ebband-flow irrigation had longer stems, higher shoot dry weight, and more thrips feeding damage than those of any other treatment. The larger thrips populations on plants grown undisturbed with ebb-and-flow irrigation may have been due to the higher relative humidity under these conditions, which improves thrips survival (Shipp and Gillespie, 1993).

Brushing or drought conditioning reduced watermelon growth and the number of thrips feeding scars in June 1992, indicating a 50\% reduction in thrips populations relative to the nontreated plants (Table 2). Watermelon plants grown with ebb-and-flow irrigation were also smaller and had fewer feeding scars than the nontreated, overheard-irrigated plants. In June 1992, eggplant growth also was reduced by brushing, drought, or ebb-and-flow irrigation, but the thrips population, as indicated by number of feeding scars, was reduced $\approx 70 \%$ on the brushed plants relative to the nontreated plants and was highest on the ebb-and-flow plants. Although in 1993 eggplant growth again was reduced by brushing or drought, the ebb-andflow-irrigated plants were the tallest but had less dry weight than the nontreated plants.
Table 3. Effect of conditioning treatment on plant growth and aphid infestation on greenhousegrown tomato plants.

\begin{tabular}{|c|c|c|c|}
\hline Treatment & $\begin{array}{c}\text { Stem } \\
\text { length } \\
(\mathrm{cm})\end{array}$ & $\begin{array}{l}\text { Shoot } \\
\text { dry wt } \\
\text { (mg) }\end{array}$ & $\begin{array}{c}\text { No. } \\
\text { aphids/ } \\
\text { plant }\end{array}$ \\
\hline \multicolumn{4}{|l|}{ April 1993} \\
\hline Nontreated ${ }^{z}$ & $35.5 \mathrm{a}^{\mathrm{y}}$ & $1276 \mathrm{a}$ & $2.6 \mathrm{a}$ \\
\hline Brushed & $21.9 \mathrm{~b}$ & $963 \mathrm{~b}$ & $0.4 \mathrm{~b}$ \\
\hline Drought & $21.3 \mathrm{~b}$ & $853 \mathrm{c}$ & $0.7 \mathrm{~b}$ \\
\hline Ebb and flow & $34.7 \mathrm{a}$ & $912 b c$ & $0.4 \mathrm{~b}$ \\
\hline \multicolumn{4}{|l|}{ May 1993} \\
\hline Nontreated $^{z}$ & $36.1 \mathrm{~b}$ & $1301 \mathrm{a}$ & $1.5 \mathrm{a}$ \\
\hline Brushed & $21.8 \mathrm{c}$ & $909 \mathrm{c}$ & $0.1 \mathrm{~b}$ \\
\hline Drought & $19.1 \mathrm{~d}$ & $630 \mathrm{~d}$ & $0.7 \mathrm{ab}$ \\
\hline Ebb and flow & $43.5 \mathrm{a}$ & $1093 \mathrm{~b}$ & $1.6 \mathrm{a}$ \\
\hline
\end{tabular}

${ }^{2}$ Nontreated, but overhead-irrigated.

yMean separation within column and experiment by Fisher's protected LSD at $P<0.05$.

Under the more severe infestation in 1993, brushing reduced thrips populations $70 \%$, as indicated by the percentage of leaf area damaged; ebb-and-flow irrigation increased thrips damage on eggplant, relative to the nontreated, overhead-irrigated plants.

Aphids. Tomato plant growth was reduced, relative to those not treated, by brushing or drought conditioning in both experiments, but again, ebb-and-flow-irrigated plants responded 
Table 4. Effect of conditioning treatment on plant growth, aphid infestation, and incidental thrips damage of greenhouse-grown watermelon or eggplant.

\begin{tabular}{|c|c|c|c|c|c|}
\hline \multirow[b]{2}{*}{$\begin{array}{l}\text { Crop and } \\
\text { treatment }\end{array}$} & \multirow{2}{*}{$\begin{array}{l}\text { Stem } \\
\text { length } \\
(\mathrm{cm})\end{array}$} & \multirow{2}{*}{$\begin{array}{l}\text { Shoot } \\
\text { dry wt } \\
(\mathrm{mg})\end{array}$} & \multirow{2}{*}{$\begin{array}{c}\text { No. } \\
\text { aphids/ } \\
\text { plant }\end{array}$} & \multicolumn{2}{|c|}{ Thrips } \\
\hline & & & & $\begin{array}{c}\text { Feeding } \\
\text { scars/plant }\end{array}$ & $\begin{array}{c}\text { Leaf area } \\
\text { damaged }(\%)\end{array}$ \\
\hline \multicolumn{6}{|c|}{ Watermelon-Apr. 1993} \\
\hline Nontreated $^{\mathrm{z}}$ & $29.9 \mathrm{a}^{\mathrm{y}}$ & $1048 \mathrm{a}$ & 0.6 & 5.2 & 10 \\
\hline Brushed & $21.3 \mathrm{c}$ & $986 \mathrm{a}$ & 0.0 & 4.4 & 6 \\
\hline Drought & $18.0 \mathrm{~d}$ & $742 \mathrm{~b}$ & 0.1 & 5.4 & 9 \\
\hline Ebb and flow & $23.5 \mathrm{~b}$ & $769 \mathrm{~b}$ & 0.1 & 5.1 & 7 \\
\hline \multicolumn{6}{|c|}{ Eggplant-Apr. 1993} \\
\hline Nontreated & $19.3 \mathrm{a}$ & $706 \mathrm{a}$ & 18.0 & $---y^{y}$ & $64 \mathrm{~b}$ \\
\hline Brushed & $14.9 \mathrm{~b}$ & $650 \mathrm{~b}$ & 12.4 & --- & $17 \mathrm{c}$ \\
\hline Drought & $11.7 \mathrm{c}$ & $574 \mathrm{c}$ & 17.6 & --- & $34 \mathrm{c}$ \\
\hline Ebb and flow & $19.8 \mathrm{a}$ & $456 \mathrm{~d}$ & 20.6 & --- & $88 \mathrm{a}$ \\
\hline \multicolumn{6}{|c|}{ Eggplant-May 1993} \\
\hline Nontreated & $20.1 \mathrm{a}$ & $902 \mathrm{a}$ & $0.4 \mathrm{~b}$ & $---x$ & $12 \mathrm{~b}$ \\
\hline Brushed & $16.7 \mathrm{~b}$ & $883 \mathrm{a}$ & $0.1 \mathrm{~b}$ & --- & $7 \mathrm{~b}$ \\
\hline Drought & $9.6 \mathrm{c}$ & $360 \mathrm{c}$ & $0.4 \mathrm{~b}$ & --- & $10 \mathrm{~b}$ \\
\hline Ebb and flow & $17.1 \mathrm{~b}$ & $530 \mathrm{~b}$ & $1.9 \mathrm{a}$ & --- & $76 \mathrm{a}$ \\
\hline
\end{tabular}

${ }^{2}$ Nontreated, but overhead-irrigated.

${ }^{y}$ Mean separation within column and experiment by Fisher's protected LSD at $P<0.05$. Nonsignificant differences in columns lack letters.

${ }^{x}$ Due to extensive feeding damage, individual feeding scars could not be detected.

differently in each experiment (Table 3). Although plants grown with ebb-and-flow irrigation in the April test had the same stem length as the nontreated controls, plants under ebb-and-flow irrigation in May were taller than the nontreated, overhead-irrigated controls. In both experiments, shoot dry weight was reduced under ebb-and-flow irrigation relative to those not treated. In Apr. 1993, aphid populations were highest on the nontreated tomato plants but similar among the other treatments. In May 1993, only the brushed plants had fewer aphids than the nontreated plants.

In Apr. 1993, watermelon stem length was reduced by all conditioning treatments, but there were no significant differences in the number of aphids, thrips feeding scars, or percent leaf damage relative to the nontreated plants (Table 4). With eggplant, under substantial aphid population development in the Apr. 1993 test, conditioning treatments did not significantly reduce aphid counts. Under the lower population levels of May 1993, eggplants under ebb-and-flow irrigation had slightly more aphids than under the other treatments, which is contrary to previous findings (Wyatt, 1969). In both experiments with aphids and with all three vegetable species, the aphid populations tended to be lowest on brushed plants but were only significantly lower than the nontreated plants for tomato.

In the incidental thrips infestation in the experiments with aphids, thrips damage on watermelon was about equal for all treatments (Table 4). However, in the Apr. 1993 test, thrips damage to eggplant was reduced $>73 \%$ by brushing and $47 \%$ by drought, but it was $27 \%$ greater on the ebb-and-flow-irrigated plants relative to the nontreated plants. Ebband-flow-irrigated eggplants also exhibited much more leaf-area damage due to higher thrips populations in the May 1993 test.

Generally, brushing reduced thrips popu- lations on eggplant, tomato, and watermelon transplants. We do not know whether this response is due to physiological changes in the plants or to the mechanical disturbance. Brushing would elicit many of the same phytochemical responses as mild leaf wounding, which generally induces insect resistance in as little as $24 \mathrm{~h}$ (Smith, 1988). Because the thrips were free to select the preferred host plants, brushing apparently induced resistance to thrips, particularly in tomato. Drought conditioning did not consistently alter thrips populations as indicated by feeding damage. The effect of plant stress on thrips host selection or population development has not been explored previously and requires additional research. Plants grown undisturbed with ebb-and-flow irrigation tended to exhibit the highest thrips populations, perhaps due to higher humidity in the microenvironment (Shipp and Gillespie, 1993)

Generally, brushing reduced aphid populations. Differences in crop biochemistry, leaf type or the specific location of aphid infestation (i.e., the shoot tip of tomato vs. a general infestation of eggplant) may have resulted in the greater effect of brushing on aphid populations on tomato. However, drought conditioning did not consistently reduce aphid counts on all species, which is not consistent with Wearing's (1967) results where aphid (M. persicae) fecundity on young and mature leaves increased with increasing water shortage but decreased on older leaves.

Drought conditioning did not consistently reduce pest populations on any of the tested crops, but it also did not result in higher pest populations. However, brushing reduced thrips populations, as indicated by feeding damage, $30 \%$ to $60 \%$ on tomato, $70 \%$ on eggplant, and $40 \%$ to $50 \%$ on watermelon transplants. Brushing also reduced aphid populations on tomato transplants by $>85 \%$ and tended to reduce aphid counts on eggplant and watermelon, or a more succulent leaf. with a $>31 \%$ reduction in aphid counts in each experiment compared to nontreated plants. Brushing for transplant height control would be a beneficial addition to an IPM program by reducing thrips and aphid populations in the greenhouse. The other benefits and potential problems with brushing for height control of vegetable transplants have been reviewed (Latimer, 1991). Although, we found no disease in our experiments, additional research must be performed to evaluate the impact of brushing on dispersal of other insect or disease organisms before brushing can be incorporated into IPM recommendations.

\section{Literature Cited}

Baden, S.A. and J.G. Latimer. 1992. An effective system for brushing vegetable transplants for height control. HortTechnology 2:412-414.

Broadbent, A.B., J.A. Matteoni, and W.R. Allen. 1990. Feeding preferences of the western flower thrips, Frankliniella occidentalis (Pergande) (Thysanoptera: Thripidae), and incidence of tomato spotted wilt virus among cultivars of florist's chrysanthemum. Can. Entomol. 122:1111-1117.

Campbell, B.C. 1988. The effects of plant growth regulators and herbicides on host plant quality to insects, p. 205-247. In: E.A. Heinrichs (ed.). Plant stress-insect interactions. Wiley, New York.

Higgins, C.J. 1992. Western flower thrips (Thysanoptera: Thripidae) in greenhouses: Population dynamics, distribution on plants, and association with predators. J. Econ. Entomol. 85:1891-1903.

Jaffe, M.J. and F.W. Telewski. 1984. Thigmomorphogenesis: Callose and ethylene in the hardening of mechanically stressed plants, p. 79-95. In: B.N. Timmermann, C. Steelink, and F.A. Loewus (eds.). Phytochemical adaptations to stress. Plenum Press, New York.

Latimer, J.G. 1991. Mechanical conditioning for control of growth and quality of vegetable transplants. HortScience 26:1456-1461.

Littell, R.C., F.J. Freund, and P.C. Spector. 1991. SAS system for linear models. SAS Institute, Cary, N.C.

Shipp, J.L. and T.J. Gillespie. 1993. Influence of temperature and water vapor pressure deficit on survival of Frankliniella occidentalis (Thysanoptera: Thripidae). Environ. Entomol. 22:726-732.

Smith, C.M. 1988. Effects of mechanical damage to plants on insect populations, p. 321-340. In: E.A. Heinrichs (ed.). Plant stress-insect interactions. Wiley, New York.

Tingey, W.M. and S.R. Singh. 1980. Environmental factors influencing the magnitude and expression of resistance, p. 86-113. In: F.G. Maxwell and P.R. Jennings (eds.). Breeding of plants resistant to insects. Wiley, New York.

Wearing, C.H. 1967. Studies on the relations of insect and host plant. II. Effects of water stress in host plants on the fecundity of Myzus persicae (Sulz.) and Brevicoryne brassicae (L.). Nature 213:1052-1053.

White, T.C.R. 1984. The abundance of invertebrate herbivores in relation to the availability of nitrogen in stressed food plants. Oecologia 63:90105.

Wyatt, I.J. 1969. Factors affecting aphid infestation of chrysanthemums. Ann. Applied Biol. 63:331337. 